\title{
Acessibilidade em bens patrimoniais: reflexões por meio de proposta de espaço de lazer infantil no Parque do Flamengo, R.J.
}

\author{
Accessibility in heritage assets: reflections through the proposal of a \\ children's leisure space in Parque do Flamengo, R.J.
}

\author{
LUCIANA BERNARDES SECRON \\ Mestrado, PROARQ UFRJ, lusecron@hotmail.com \\ CRISTANE ROSE DE SIQUEIRA DUARTE \\ Doutorado, PROARQ UFRJ, crsduarte@gmail.com
}

\section{RESUMO}

O artigo traz a reflexão sobre a importância da acessibilidade ao patrimônio cultural, principalmente no que diz respeito à abertura desse patrimônio para crianças com deficiência. Para fomentar essa discussão, com base nos conceitos de acessibilidade emocional e ambiência, o artigo se apoia em uma proposta projetual no Parque do Flamengo, por meio de um trabalho que precisou desenvolver metodologias adaptadas para o entendimento da percepção e da geração de afetos em crianças. Os resultados demonstram que as ações de intervenção não devem ser encaradas como barreiras para a preservação do bem cultural. A partir do entendimento de que a acessibilidade agrega valor ao uso, devemos incorporar seus conceitos nos projetos de intervenção, para que o próprio bem atenda suas funções sociais para todos.

PALAVRAS-CHAVE: lazer infantil; ambiência; acessibilidade; Parque do Flamengo; patrimônio arquitetônico

\section{ABSTRACT}

This article presents a reflection on the importance of accessibility to cultural heritage, in particular as regards the opening of this heritage to disabled children. To promote this discussion, based on the concepts of emotional accessibility and atmosphere, the article is based on a project proposal at Parque do Flamengo, through work that had to develop suitable methodologies to understand the perception and generation of affects in children. The results demonstrate that intervention actions should not be considered as obstacles to the preservation of cultural property. Starting from the principle that accessibility adds value to use, we must integrate these concepts into intervention projects, so that the good itself fulfills its social functions for all.

KEYWORDS: children's leisure, accessibility, Flamengo Park, architectural and landscape heritage 


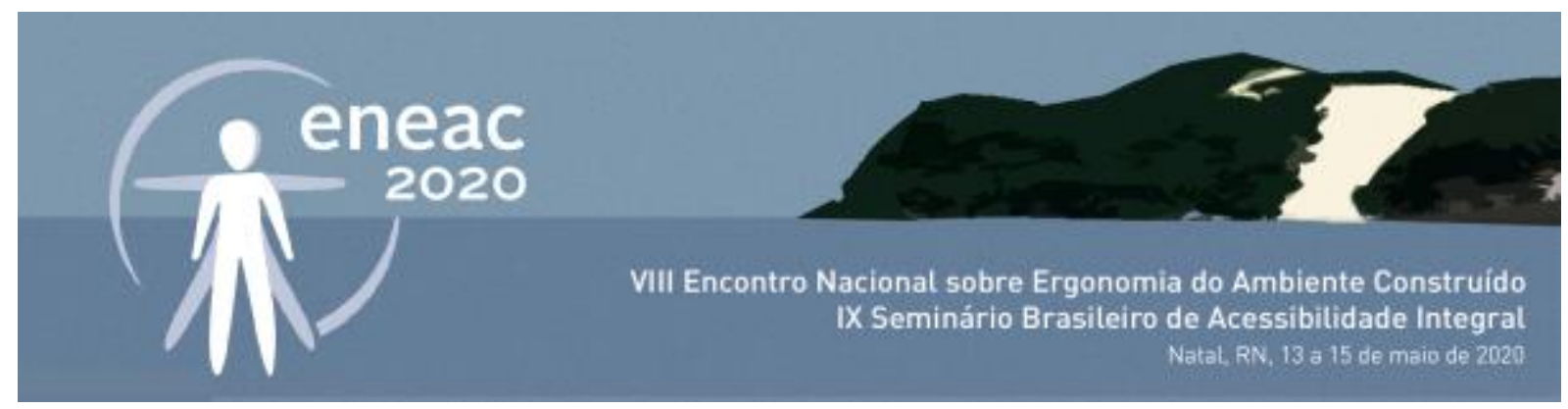

\section{INTRODUÇÃO}

A preservação do patrimônio representa a continuidade de sua existência, que poderá perpetuar para gerações futuras sua riqueza cultural. Para que o patrimônio se perpetue é importante que as pessoas o reconheçam como um bem e que este tenha valor de uso para ser preservado.

Para CARSALATE (2011, p.3), "a arquitetura é uma arte que se faz em função do uso e é feita para servir e materializar as sociedades". Portanto precisa ter essa propriedade de uso mantida para sobreviver ao tempo. Compreende-se, assim, que tanto o edifício quanto a cidade e a paisagem, estão em constante mutação, diferente de um quadro ou uma escultura. Ou seja, por ser um elemento vivenciado pelas pessoas, o uso do bem patrimonial está intrínseco em sua existência. Dessa maneira, consegue unir as ligações emocionais de identidade com o bem e de funcionalidade necessárias para seu uso.

Contudo, se a importância do uso do patrimônio aparece em diversos discursos, parece-nos ainda existir uma lacuna no que se refere a esse uso por pessoas com deficiência. Se o patrimônio cultural arquitetônico deve ser vivenciado pelas pessoas para que se permaneça vivo, como as pessoas com deficiência que são impossibilitadas de vivenciar esse espaço conseguem reconhecê-lo como patrimônio?

Na verdade, se por um lado o uso do bem cultural é garantido a todos os cidadãos pelas leis e normas que regem seus direitos, por outro, as ações de intervenção para a implantação de acessibilidade em bem culturais esbarram em entraves da própria lei de preservação e do descaso em relação a esta parcela da população que sofre com a deficiência de espaços acessíveis.

A legislação que protege e garante os direitos das pessoas com deficiência se efetiva demonstrando pouco a pouco as conquistas que vêm sendo realizadas a favor de uma sociedade igualitária. Dentre algumas das principais leis que configuraram essas conquistas, pode se destacar a Lei Brasileira de Inclusão (LBI), conhecida também como Estatuto da Pessoa com Deficiência datada de 06 de julho de 2015. A LBI passou a organizar em uma única lei nacional um verdadeiro marco regulatório para as pessoas com deficiência, direitos e deveres que estavam dispersos em outras leis, decretos e portarias, regulamentando limites e condições e atribuindo responsabilidades para cada responsável na consolidação da sociedade inclusiva.

A acessibilidade ao patrimônio na LBI é integrada em conjunto com referências normativas. Devem ser atendidas as normas de acessibilidade e de proteção do patrimônio. Estas são regidas principalmente pela ABNT NBR9050 e a Instrução Normativa n1 do IPHAN. Nesta Normativa são estabelecidas diretrizes e critérios para a promoção da acessibilidade aos bens culturais, de modo que a sociedade possa usufruí-lo, incluindo as pessoas com deficiência e mobilidade reduzida.

Entretanto, esta Normativa afirma que cada intervenção de adequação para acessibilidade deve ser "limitada" pela possibilidade de "comprometimento do valor testemunhal e da integridade estrutural resultantes" (item 1,1,c). Esse posicionamento, pode, em muitos casos, não permitir que o mesmo seja acessível em sua integridade, posto que a proposta de adequação pode ser considerada pelos órgãos de preservação, como uma "descaracterização". Ainda que a lei brasileira garanta os direitos da acessibilidade ao patrimônio cultural, encontrar a melhor solução sua promoção é de fato um grande desafio. 


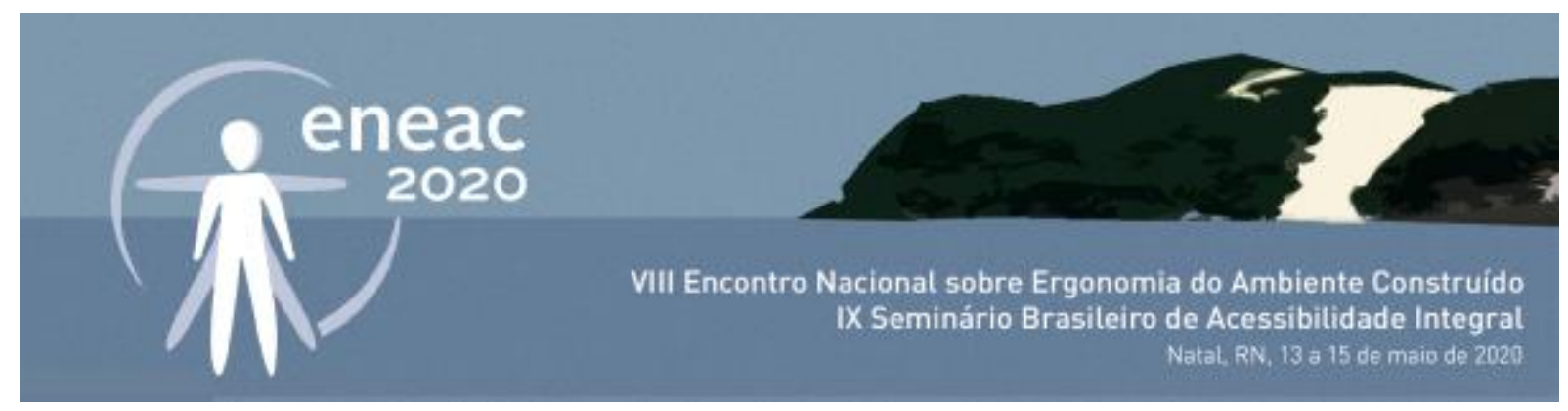

O trabalho que aqui estamos apresentando buscamos comprovar que é possível conferir acessibilidade ao bem patrimonial sem descaracterizá-lo, transformando o uso do lugar e estimulando o sentimento de pertencimento que todo patrimônio deveria provocar na sociedade.

Desta forma, o trabalho que está na base deste artigo (referência ao trabalho omitida para revisão cega) tomou como estudo de caso a Cidade das Crianças, que está inserida no Parque do Flamengo, Rio de Janeiro, tombado e Inserido no sítio do Patrimônio Mundial da Paisagem Cultural da Cidade.

No projeto de estudo, as leis brasileiras foram utilizadas como referência para a fundamentação do projeto de intervenção em área de lazer do patrimônio cultural, visando democratizar o espaço em respeito à dignidade humana.

\section{CONCEITOS}

A acessibilidade com qualidade aos espaços e o respeito aos princípios do desenho universal são condições que conferem cidadania, pois englobam não só as questões de mobilidade, mas também a experimentação dos lugares em igualdade com todos os usuários.

As pessoas com deficiência apresentam condições diversas e limitações, porém, seus anseios pela experimentação do espaço não são diferentes dos de qualquer cidadão. Assim, como defendem diversos autores dedicados ao assunto (PRADO , LOPES e ORNSTEIN, 2010), para que todos os usuários tenham a possibilidade de experimentar os espaços em situação de igualdade, as políticas governamentais deveriam efetivar na prática todo o conhecimento e a aplicação dos direitos já conquistados através de Leis e Normas de acessibilidade.

Ainda que esses direitos de igualdade social estejam garantidos pela legislação, no caso dos bens culturais tombados, existe a questão da preservação sobre as ações de intervenção para promover a acessibilidade. A Normativa №1, elaborada pelo IPHAN, afirma que as ações devem ser limitadas pela possibilidade de "comprometimento do valor testemunhal e da integridade estrutural resultantes" (item 1,1,c). Esse posicionamento que ao mesmo tempo busca promover a acessibilidade ao patrimônio cultural, pode não permitir que o mesmo seja acessível em sua integridade, posto que a proposta de adequação pode ser considerada pelos órgãos de preservação, como uma descaracterização do mesmo. Encontrar a melhor solução para a promoção da acessibilidade é de fato um grande desafio.

No projeto de estudo, as leis brasileiras foram utilizadas como referência para a fundamentação do projeto de intervenção em área de lazer do patrimônio cultural, visando democratizar o espaço em respeito à dignidade humana. Muito mais que isto, o presente trabalho sustenta que, ao buscar a qualidade dos espaços, todo projeto precisa pensar além da simples obediência às regras, normas e leis. Nesse sentido, as bases do presente trabalho se apoiam nos conceitos de Desenho Universal, Acessibilidade Emocional e Ambiência.

A concepção do Desenho Universal foi uma conquista significativa no que tange ao acesso universal, ampliando a questão da acessibilidade além das barreiras arquitetônicas, incorporou os conceitos da acessibilidade atitudinal metodológica, instrumental e programática. No conceito de Desenho Universal é buscada a ampliação do uso ao maior gama possível de pessoas. Dentro dessa concepção, a acessibilidade já começa a ser pensada no processo de planejamento do projeto e assume um caráter inclusivo igualitário para todos, sem segregação de espaços que definam onde o usuário pode circular. 


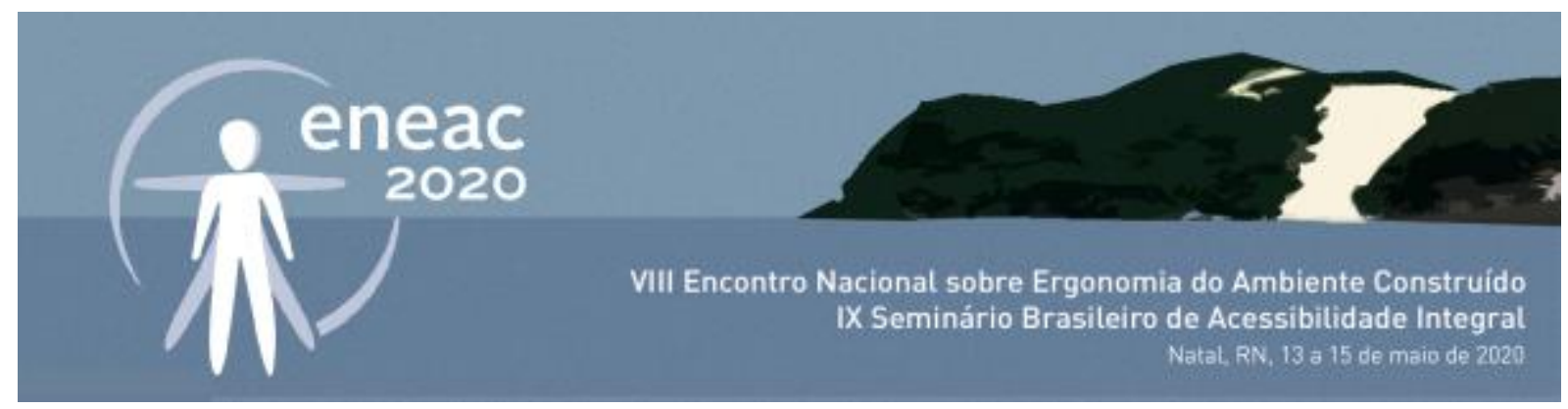

Por sua vez, no conceito de Acessibilidade Emocional (DUARTE E COHEN, 2012) são incorporados ao conceito de acessibilidade os aspectos sensoriais e afetivos da relação que o usuário possui com o espaço. Ao se considerar todos os usuários, com deficiência ou não, essa relação também estimulada pelos fatores sensoriais, potencializa a relação emocional com o espaço, transforma este em lugar e fortalece os vínculos afetivos e sociais de um grupo. O conceito de Acessibilidade Emocional considera que, ainda que um espaço atenda a todas as questões normativas de acessibilidade, incluindo as premissas do Desenho Universal, "não é capaz de promover condições agradáveis de experienciação do Lugar" se não for levada em conta a empatia espacial (DUARTE e COHEN, 2018, p.3). Nesse sentido, a Acessibilidade Emocional se apresenta de maneira mais sensível e subjetiva nas questões de planejamento urbano e arquitetônico. Há que se pensar nas questões afetivas e emocionais da relação do homem com o espaço, para que este transmita um sentimento de empatia, fazendo o homem se sentir acolhido e pertencente ao Lugar.

A Ambiência é um conceito que abarca o lugar urbano e os sentidos de seus usuários. Sua leitura se dá através do corpo percebendo um determinado espaço. Essa leitura apresenta uma compreensão do espaço por um ângulo mais humano e sensível. Os aspectos sensíveis do lugar fazem emergir sentimentos de afeto e pertencimento enquanto são percebidos e traduzidos ao se experienciar o espaço, captando, pela antena do corpo e pela percepção da sonoridade, da iluminação, das possibilidades olfativas, da temperatura e da ventilação.

De acordo com Thibaud (2013), a ambiência é definida como o espaço-tempo experimentado pelos sentidos. Afirma o autor que a criação de ambiências não atua apenas no contexto material e físico da cidade, mas também em seus componentes imateriais. Para Thibaud e Duarte, (2013), a ambiência desperta uma interpretação subjetiva pessoal a partir de uma experiência coletiva. Como a sensação de um ser humano no contexto urbano, que compartilha percepções com diversos usuários e mesmo com sentimentos distintos, dessa troca é reconhecida uma ambiência. Entender a relação entre pessoa e ambiente e identificar quais elementos provocam apego ou rejeição é uma forma de análise do espaço urbano que pode enriquecer os projetos urbanos.

\section{APRESENTAÇÃO DO ESTUDO DE CASO}

Como dito mais acima, a partir de uma proposta de revitalização de um espaço patrimonial, o objetivo deste trabalho foi o de mostrar que é possível conferir acessibilidade e qualidade de uso para todos, ampliando o valor afetivo do lugar sem "descaracterizar" o bem tombado.

Para tal estudo exploratório foi selecionada a área de lazer infantil denominada Parque das Crianças, inserida no Parque do Flamengo, situado na cidade do Rio de Janeiro (Figuras 1 e 2). 


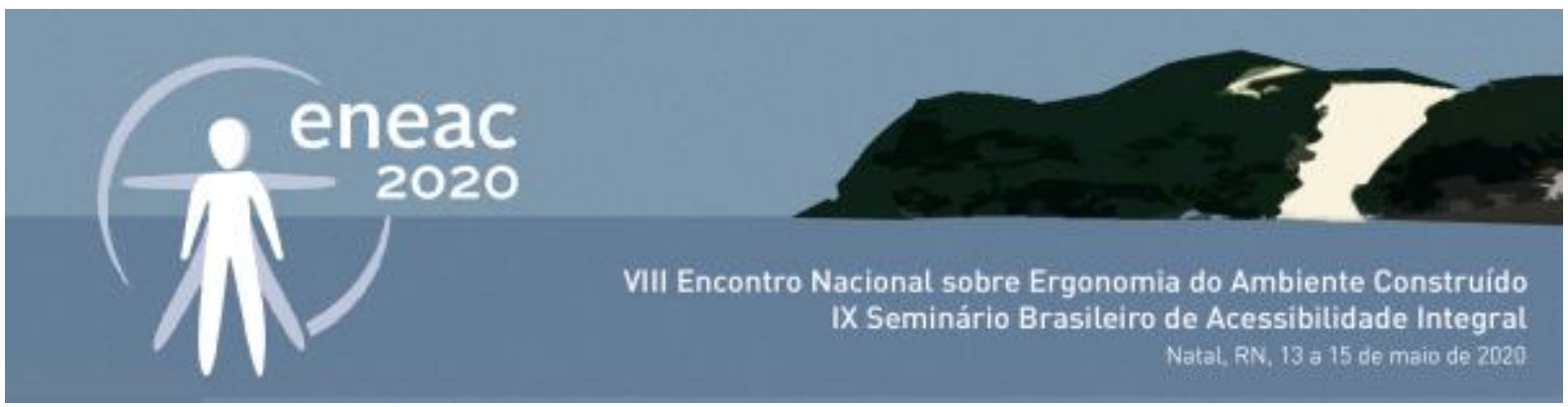

Figura 1: Vista aérea do Parque do Flamengo

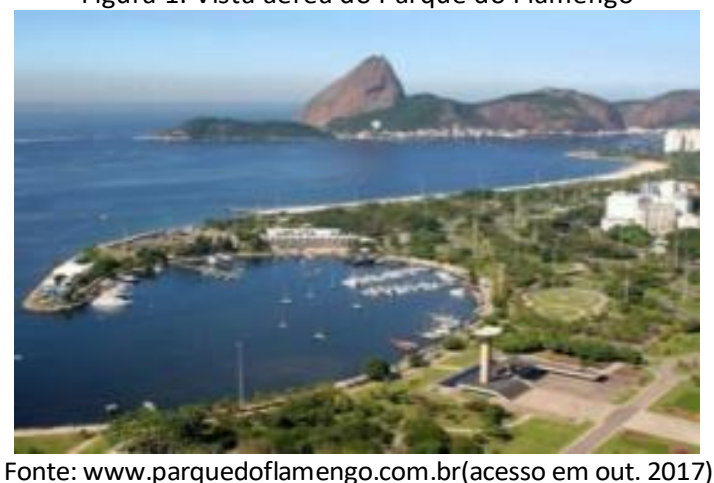

Figura 2: Situação do Parque do Flamengo e Pq. da Crianças

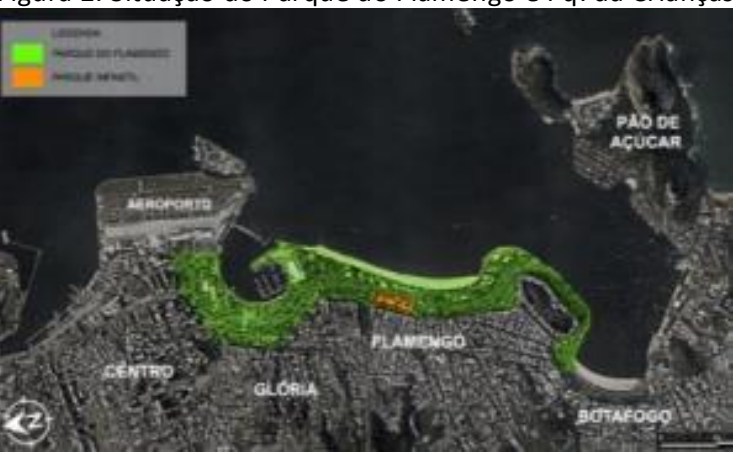

Fonte: Base google maps, adaptado pelas autoras

O Parque do Flamengo é um parque público que apresenta um grande valor cultural, reconhecido pela população como obra e espaço de lazer. Seu projeto idealizado por um grupo multidisciplinar de trabalho que teve à sua frente o arquiteto Affonso Eduardo Reidy, como responsável pelo projeto de urbanização e arquitetura do parque. Sua inauguração foi realizada em 1965, mesmo ano de seu tombamento. A implantação do parque foi um sucesso e o Parque logo se tornou um refúgio de lazer e contemplação da natureza para os cariocas.

Inserido no sítio do Patrimônio Mundial da Paisagem Cultural da Cidade, título concedido à Cidade do Rio de Janeiro em 2012 pela UNESCO, o Parque do Flamengo reforça sua referência como um bem cultural, que deve ser preservado e acessível a toda população (Dossiê UNESCO, 2017).

Situado na área central do parque do Flamengo, o Parque das Crianças ocupa uma área de aproximadamente $33.000 \mathrm{~m}^{2}$. Esse espaço tem como referência a edificação do Pavilhão Japonês, atual sede administrativa do Parque do Flamengo. O projeto de lazer e recreação foi desenvolvido por Ethel Bauzer Medeiros. Havia uma preocupação em construir não só um espaço com equipamentos de lazer atrativos mas que tivesse atividades de lazer programadas por profissionais de forma a oferecer às crianças, atividades com qualidade. Atualmente o local se encontra com usos que entram em conflito com estas atividades, além de apresentar sérios problemas de conservação.

Para a compreensão de nossas propostas cabe alinhavar um resumo das condições atuais do local.

Logo em seu acesso principal encontramos uma situação problemática devido ao abandono de gatos no local. Os animais estão por toda a parte, causando mau cheiro e consequentes riscos de doenças às pessoas que frequentam o parque.

Ao redor do Pavilhão Japonês, a edificação de referência do parque, podemos perceber um grande espaço livre que é ocupado com o uso de estacionamento indevido. Diferentemente do projeto original do Parque, o espaço interno do Pavilhão não é aberto ao público. As instalações sanitárias, espaço de ambulatórios e salas, previstas para a utilização do público, são hoje de uso privativo da administração e com isso, o parque infantil fica carente dessa infraestrutura.

O espaço livre ocupado pelos brinquedos é procurado geralmente para a realização de piqueniques e comemorações de aniversários, especialmente nos feriados e aos domingos (Figura 3). Mesmo apresentando mau cheiro, as pessoas frequentam esse local. 


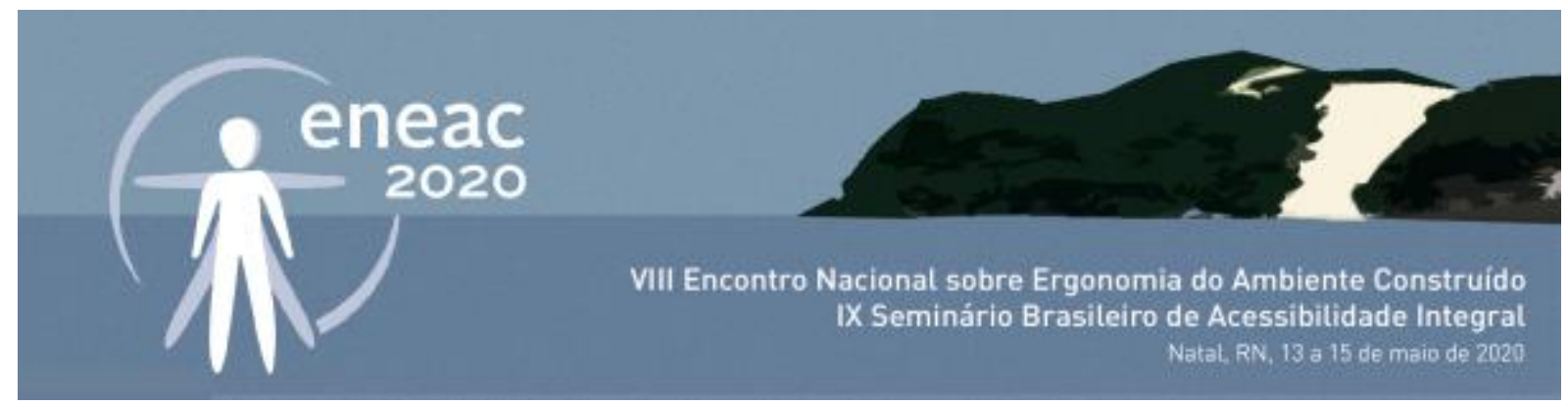

O espaço livre das quadras tem o uso para a prática de atividades desportivas e até mesmo para eventos e confraternizações. O espaço se situa uma área de grande desnível e sem acessibilidade adequada, dessa forma exclui o usuário com deficiência (Figura 4).

Em um dos espaços do Parque das Crianças está a "Cidade das Crianças", onde o uso tem passado por mudanças de apropriação e atualmente é mais utilizado pela prática da atividade de Parkour (Figura 5). Tanto esse espaço quanto a instalação ao lado com um grande tanque de areia e um escorrega em concreto, apresentam problemas pontuais de conservação e principalmente de insalubridade devido à ocupação dos espaços pelos animais (Figura 6).

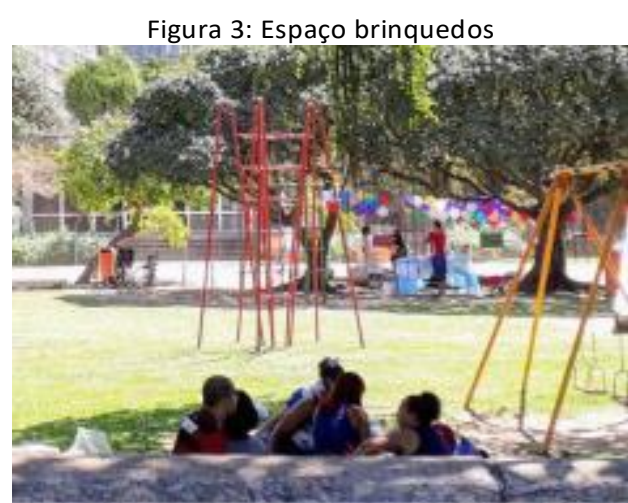

Fonte: autoras, set de 2018

Figura 5: Cidade das Crianças" ou "Cidade do Parkour"

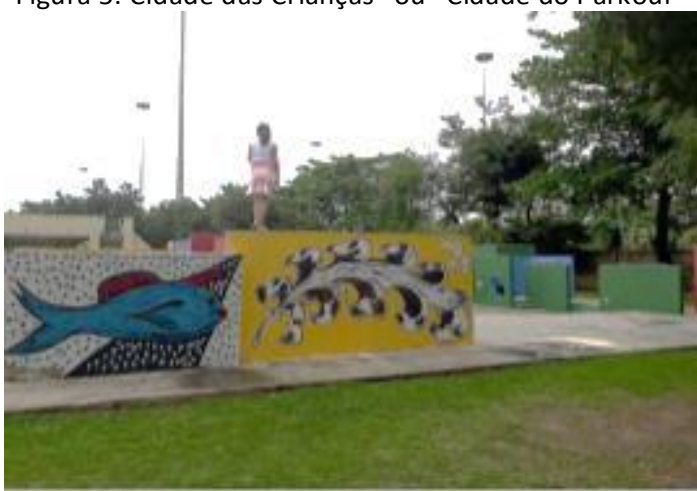

Fonte: autoras, nov de 2018
Figura 4: Espaço quadras em desnível

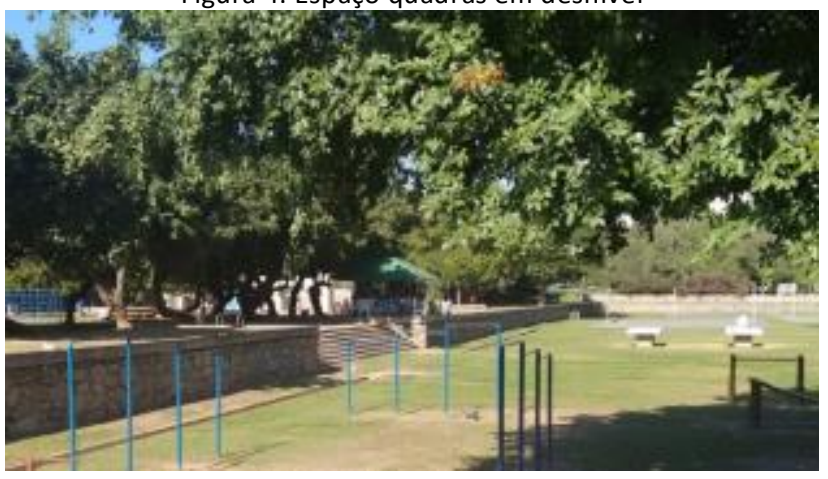

Fonte: autoras, jun de 2016

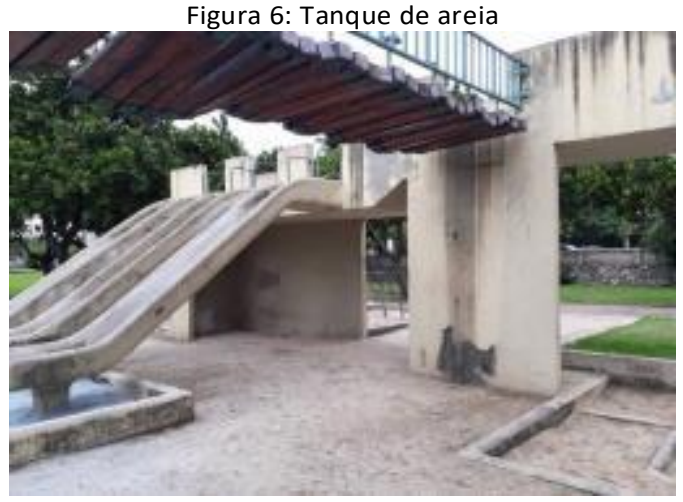

Fonte: Fotografia autoras, maio. 2018

O parque não apresenta uma infraestrutura básica de qualidade para apoio ao usuário. Os sanitários existentes localizados no Pavilhão, que no projeto original seriam abertos ao público, são atualmente de uso exclusivo da administração. Não existe mobiliário de apoio adequado e o quiosque existente para apoio de alimentação se apresenta deficitário.

Além desses pontos, a área de lazer infantil não é acessível, em nenhum dos setores foi identificado um espaço que atendesse a acessibilidade com qualidade e segurança. $O$ parque exclui esses usuários e apesar de toda diversidade de lazer oferecida pelo parque e de ser um patrimônio cultural, não oferece acesso à cultura e lazer as pessoas com deficiência. 


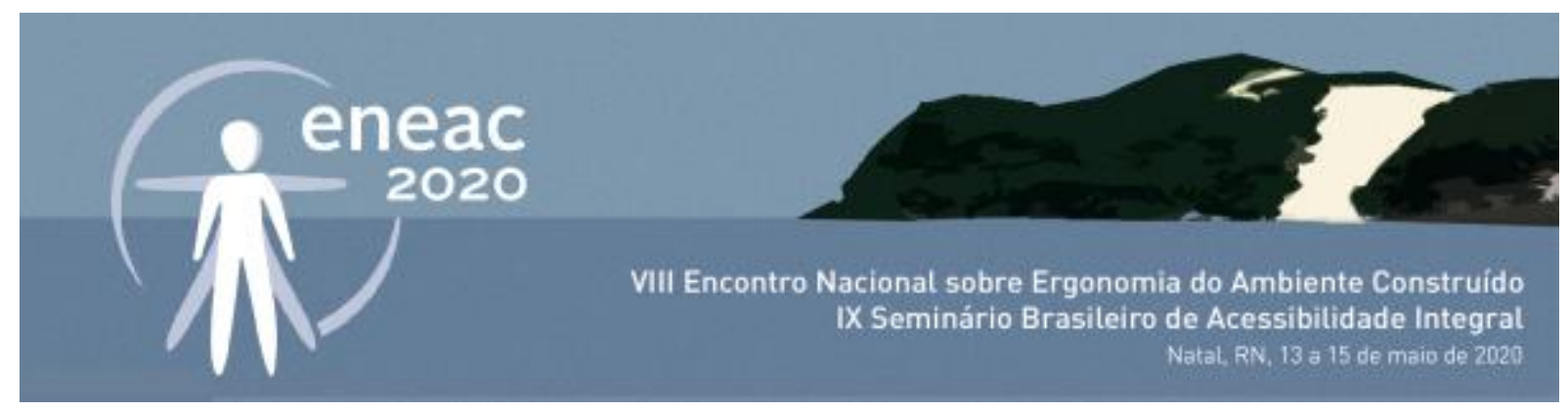

\section{METODOLOGIA APLICADA}

Por meio de uma abordagem qualitativa, foi aplicada em campo uma pesquisa de cunho etnográfico, buscando observar e relatar os fenômenos sociais praticados no local e, dessa forma, compreender melhor o uso do espaço pelos usuários.

Para implementar a pesquisa em campo, foi realizada uma dinâmica no espaço do parque com grupos de crianças. Cabe ressaltar que parte desse grupo de crianças era composto por crianças com deficiência (Tabela 1).

Tabela 1: Composição dos grupos que participaram dos percursos

\begin{tabular}{|r|l|c|c|}
\hline \multicolumn{4}{|c|}{ VISITA PERCURSOS - Grupo 1 } \\
\hline \multicolumn{2}{|c|}{ Participantes } & Idade & Tipo de Deficiência* \\
\hline 1 & I (Menina) & 10 & Não apresenta \\
\hline 2 & F. (Menino) & 4 & Não apresenta \\
\hline 3 & G. (Menina) & 10 & Não apresenta \\
\hline
\end{tabular}

* Tipo de deficiência com base no decreto 5.296/04, artigo 5 ㅇ e Lei $12.764 / 12$, artigo 1 으, §2응

Percursos realizados na Cidade das Crianças, entre novembro de 2018 e janeiro de 2019

\begin{tabular}{r|r|c|c|}
\hline \multicolumn{3}{|c|}{ VISITA PERCURSOS - Grupo 2} \\
\hline \multicolumn{2}{|c|}{ Participantes } & Idade & Tipo de Deficiência* \\
\hline 1 & LF. (Menino) & 9 & Não apresenta \\
\hline 2 & L. (Menino) & 12 & TEA (Transtorno do Espectro Autista) \\
\hline 3 & E. (Menino) & 8 & TEA (Transtorno do Espectro Autista) \\
\hline 4 & L. (Menino) & 8 & Múltipla (TEA e hipotonia) \\
\hline 5 & L. (Menina) & $\mathbf{7}$ & Não apresenta \\
\hline 6 & M. (Menino) & 10 & Múltipla (Down, baixa visão e TEA) \\
\hline 7 & J. (Menina) & 5 & Múltipla (Atraso no desenvolvimento e TEA) \\
\hline 8 & A (Menino) & 25 & Auditiva \\
\hline 9 & ME.(Menina) & 6 & TEA (Transtorno do Espectro Autista) \\
\hline 10 & D. (Menino) & 13 & TEA (Transtorno do Espectro Autista) \\
\hline
\end{tabular}

Foram usadas ferramentas metodológicas etnotopográficas (DUARTE, 2010) tais como o Mapeamento das Manifestações e os croquis de campo (DUARTE, 2010). Essa abordagem permitiu representar graficamente as percepções do usuário em relação ao espaço, identificando aspectos de relação de atração e afetividade com o ambiente ou de repulsa, levando a definições de diretrizes projetuais de intervenção no projeto arquitetônico. Da mesma forma, as análises foram apoiadas em um levantamento fotográfico e caderno de campo.

Devido à necessidade de compreensão da influência da ambiência urbana em relação ao comportamento e afetos desenvolvidos pelas pessoas no espaço, surgiu como base referencial o método dos Percursos Comentados, desenvolvido pelo sociólogo Jean Paul Thibaud (2013). Este busca captar as percepções que os usuários têm de uma determinada ambiência. Essas percepções, segundo o autor citado, são influenciadas pelo ordenamento material de uma ambiência e afetam os fenômenos sensíveis (sonoros, olfativos, lumínicos, táteis) das pessoas que vivenciam esse espaço. De acordo com o autor, essa percepção só pode ser sentida com o corpo em movimento no espaço.

Na referida metodologia, durante a realização do percurso, o usuário precisa verbalizar suas sensações e afetos em relação ao lugar. Segundo Thibaud (2013), a chave para a transmissão dessas percepções deve acontecer simultaneamente com o caminhar, a percepção e a descrição. A duração do percurso deve acontecer no máximo em vinte minutos aproximadamente e não deve ser muito extenso.

Por tratar da percepção de crianças com deficiência, foi necessário fazer ajustes nas ferramentas empregadas na presente pesquisa. Se por um lado interessava compreender as percepções desses usuários em potencial, por outro, foi constatado que seria difícil obter o relato dessas crianças por meio da metodologia de Thibaud (Percursos Comentados) se esta fosse aplicada em sua forma clássica. Da 


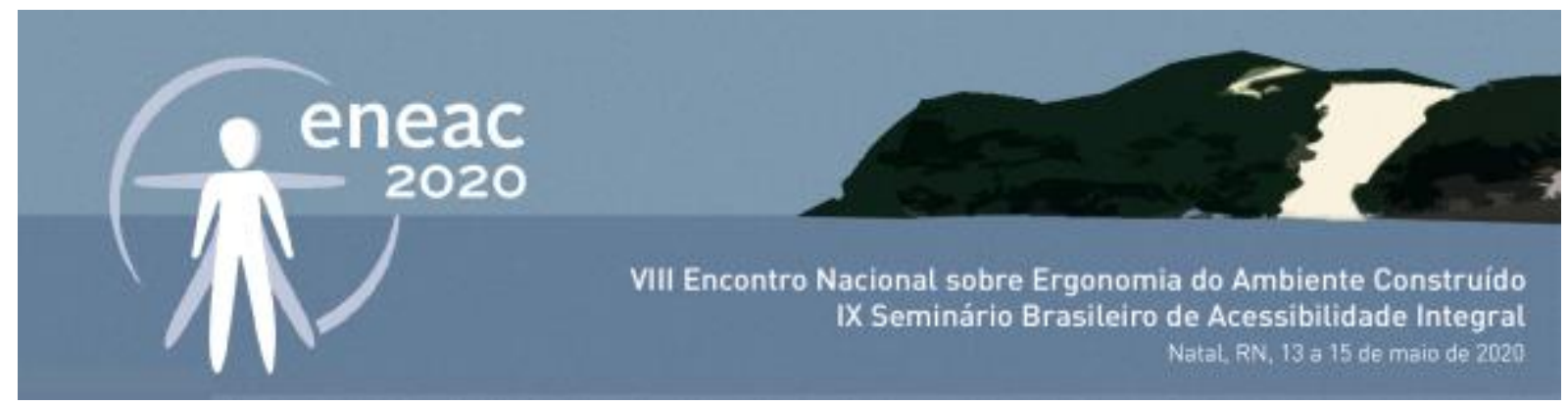

mesma forma, sentimos que seria muito difícil mapear manifestações de afeto apenas com os registros etnográficos: entendíamos que seria necessária uma comunicação mais efetiva com essas crianças.

A metodologia aplicada nesta pesquisa buscou, assim, não apenas misturar os dois métodos como, também, adaptá-los ao grupo específico de usuários que selecionamos, a saber: crianças, principalmente aquelas com deficiência. Propusemos então que o relato de suas apreciações fosse feito por meio de emoji correspondente ao sentimento em relação ao ambiente. Foram definidos quatro tipos de sentimentos de emojis: muito legal, legal, mais ou menos e não gostei, conforme demonstrado na Figura 7.

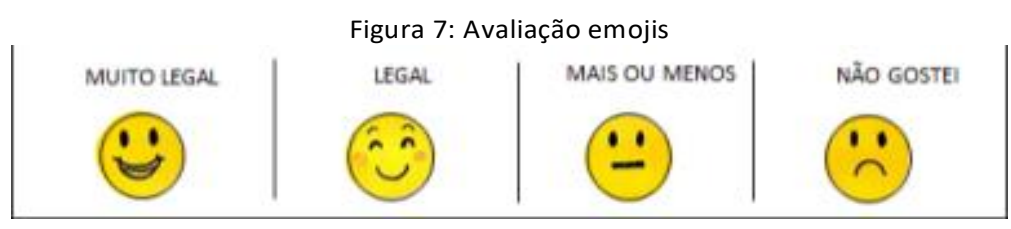

Fonte: desenvolvido pelas autoras

A escolha do emoji para representar o sentimento em relação ao espaço foi uma forma de criar uma aproximação na comunicação com os grupos. Esta representação traduziria a expressão do sentimento, pois alguns apresentam dificuldades de verbalizar suas percepções com palavras.

A dinâmica compreendeu também uma atividade onde os usuários iriam sugerir atividades para cada setor do Parque. A ideia dessa atividade foi confrontar a setorização das atividades propostas com a vontade do usuário. Além disso, verificar a possibilidade de sugestão de outras atividades (Figura 8).

Figura 8: Mapa de Atividades Propostas

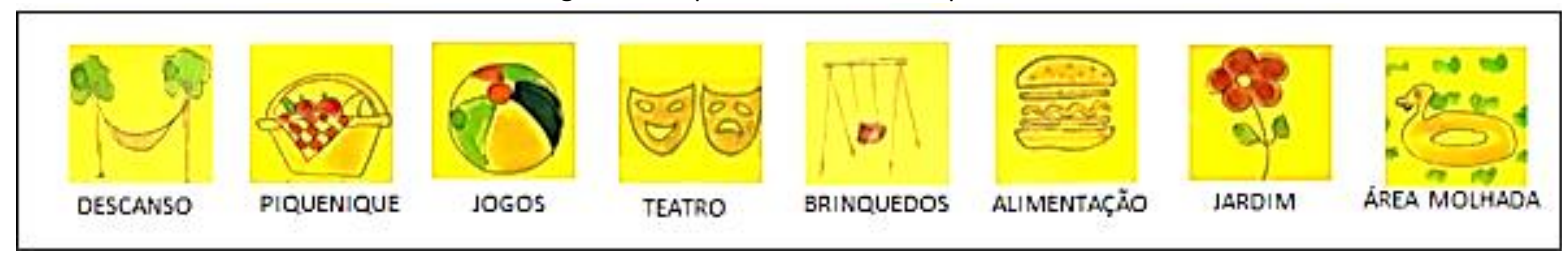

Fonte: desenvolvido pelas autoras

Para concluir o planejamento da dinâmica, após um intervalo para descanso, foi solicitado a realização de desenhos sobre as impressões do parque. O desenho foi pensado como mais uma forma de representação e expressão de seus sentimentos. De fato, devido ao planejamento de realizar a metodologia de realização do percurso com grupos de crianças, incluindo crianças com deficiência, exploramos as possibilidades de comunicação, direcionando de forma lúdica a manifestação sobre as percepções, de acordo com as limitações de cada um.

Para a realização completa do percurso, foram sugeridos os pontos de parada para a avaliação das percepções pelos setores existentes do parque (Figura 9). 


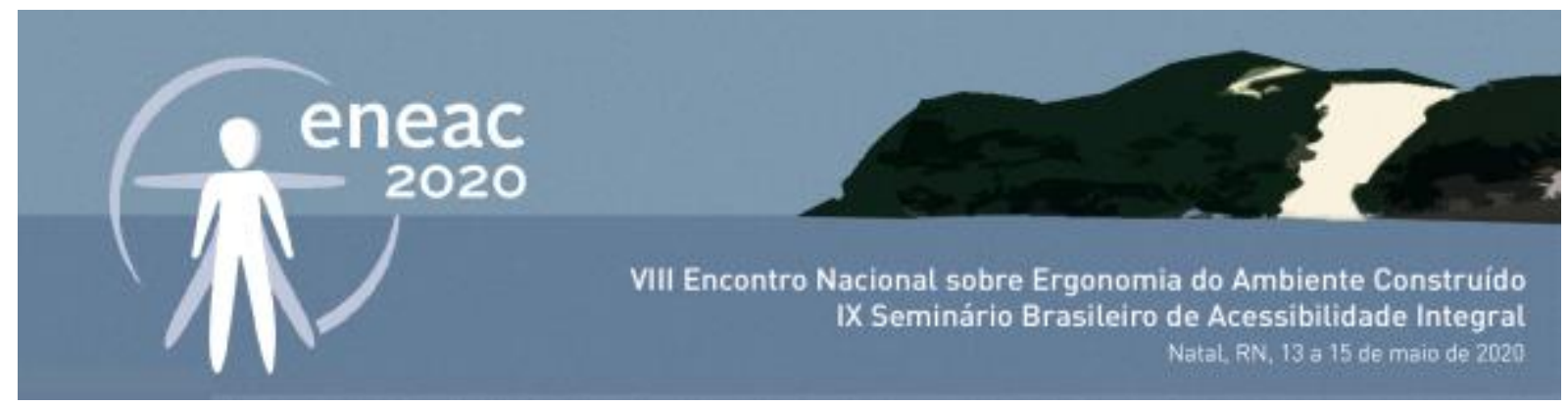

Figura 9: Mapa do Percurso

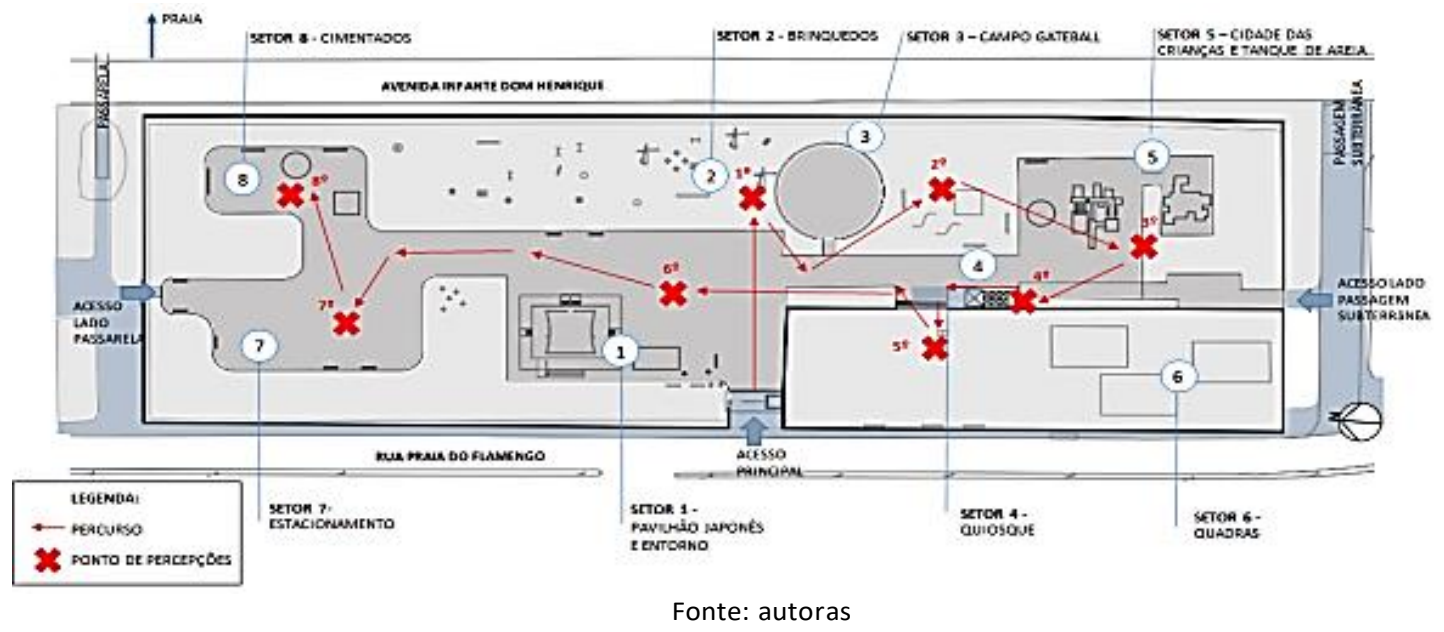

Antes da realização da dinâmica foi explicado às crianças como seria a atividade e inclusive que poderiam desistir se quisessem. Foram informadas que poderiam falar sem preocupação, tudo o que estavam sentindo em relação aos sentidos e qualquer outra percepção que tivessem. Também deveriam falar das emoções, perceber se estavam felizes, satisfeitos, acolhidos ou não com parque.

Em relação à realização do percurso individualmente, conforme descrito na metodologia de Percursos Comentados, na dinâmica com as crianças foi proposto um percurso em grupo. Esta modificação visou a uma atividade mais divertida para os grupos e mais rápida, pois como cada grupo chegaria e sairia junto do espaço, a dinâmica individual seria muito demorada.

O mapeamento das manifestações e os percursos comentados foram adaptados e representados sobre a planta baixa do parque infantil, demonstrando os resultados das dinâmicas dos percursos realizados em campo com os grupos 1 e 2 .

\section{ANÁLISE E DIAGNÓSTICO}

O registro das percepções foi realizado por anotações, fotografias e avaliações que as crianças fizeram em cada setor do parque, seguindo as representações com os emojis e desenhos de atividades. A realização dos percursos individuais não foi possível, pois no ambiente do parque as crianças recebiam estímulos diversos, se dispersavam e preferiam ficar juntas.

O tempo de realização do percurso foi bem maior do que o planejado inicialmente, que seria de vinte minutos. À medida que as crianças chegavam em um ambiente e gostavam, queriam explorá-lo, experimentá-lo e brincar. $O$ inverso também aconteceu, quando não se identificavam ou não sentiam interesse, era difícil até pararem para avaliarem o espaço. Tanto o grupo 1 quanto o grupo 2, levaram em média 60 minutos para a realização do percurso completo (Figuras 10 e 11). 


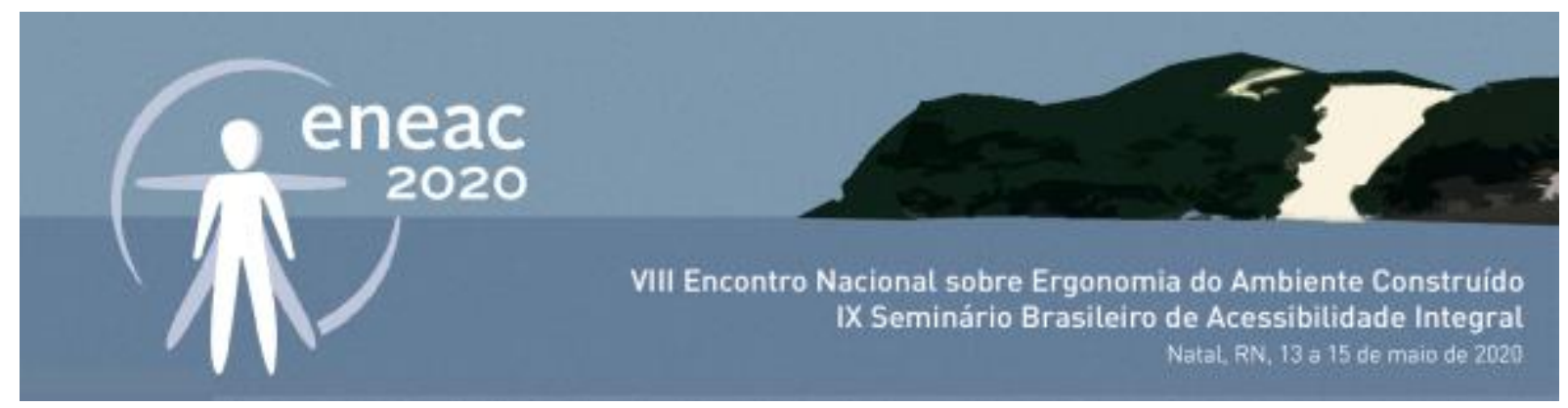

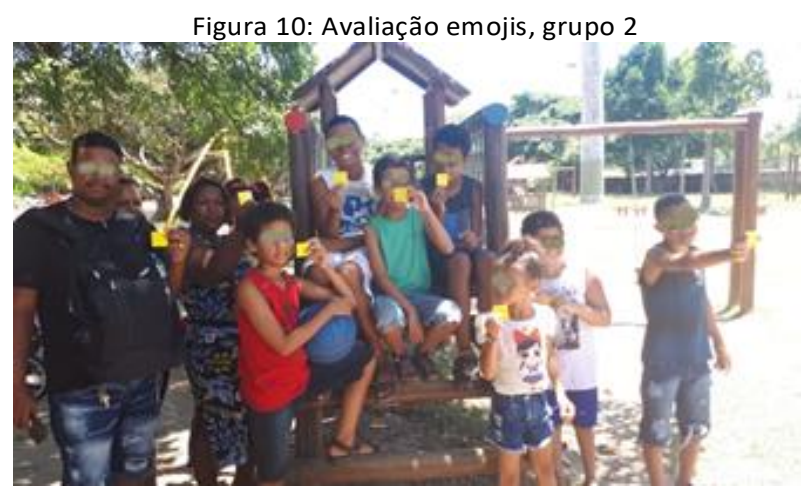

Fonte: autoras, jan de 2019

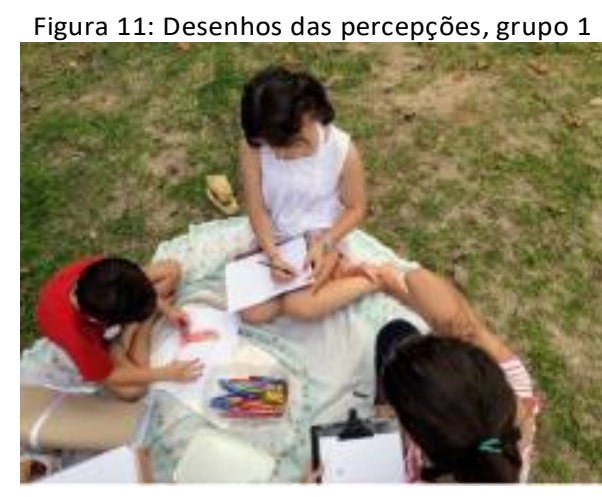

Fonte: autoras, nov de 2018 e jan de 2019

Durante a realização do percurso, além das percepções registradas de acordo com as avaliações das crianças, os responsáveis que acompanharam se manifestaram espontaneamente e seus comentários também foram registrados, assim como a percepção de suas ações e reação com o ambiente. Vale ressaltar que em um parque infantil quem leva as crianças são os responsáveis, portanto são usuários que possuem legitimidade para opinar na pesquisa, já que este espaço deve atender a todos.

Os responsáveis do grupo 2 fizeram vários comentários em relação às questões de acessibilidade, pois isso os afeta diretamente. A falta de acesso adequado e de instalações seguras e atrativas dificultaram demais a experiência. Verificou-se que, para os responsáveis, havia uma sensação de tensão sobre a preocupação dos filhos brincarem em um local não preparado para eles. Nessa situação, o desgaste físico e emocional para alguns responsáveis também foi identificado, pois por não apresentar um local seguro, precisaram se esforçar para acompanha-los mais de perto e garantir sua segurança. A experiência revelou sensação de frustração por não poderem aproveitar o espaço como gostariam, ficando mais na posição de expectadores.

$\mathrm{Na}$ atividade de desenhos, quando as crianças foram estimuladas a desenhar suas impressões do parque, os resultados foram interessantes pois alguns elementos em comum se manifestaram. Os desenhos que representam o que as crianças mais gostaram do Parque, se destacam os elementos naturais da paisagem, os brinquedos e a Cidade das Crianças ou Parkour. A representação do Pão de Açúcar e dos elementos naturais como as árvores aparece em destaque. A força da natureza do parque é afirmada nas representações como uma forma de identidade do espaço.

Os desenhos dos elementos que as crianças não gostaram do parque foram representados com as figuras de fezes de gato, representando a sujeira e o mau cheiro, os gatos abandonados e os carros. 0 gato também aparece como a principal impressão do parque no desenho de uma criança de quatro anos, que só desenhava gatos em todas as folhas oferecidas.

Como representação de elementos do que as crianças gostariam que tivesse no parque, foi representado um grande portal de entrada, neste, a criança disse que era para mostrar a entrada do parque. Uma pista de skate também foi representada para uma criança de doze anos, representando um entretenimento mais interessante para sua idade. As barraquinhas de comida e de feirinhas também foram representadas como desejo de realização. $O$ elemento água surge em forma de chafariz também como desejo de um novo espaço de lazer (Figura 12). 


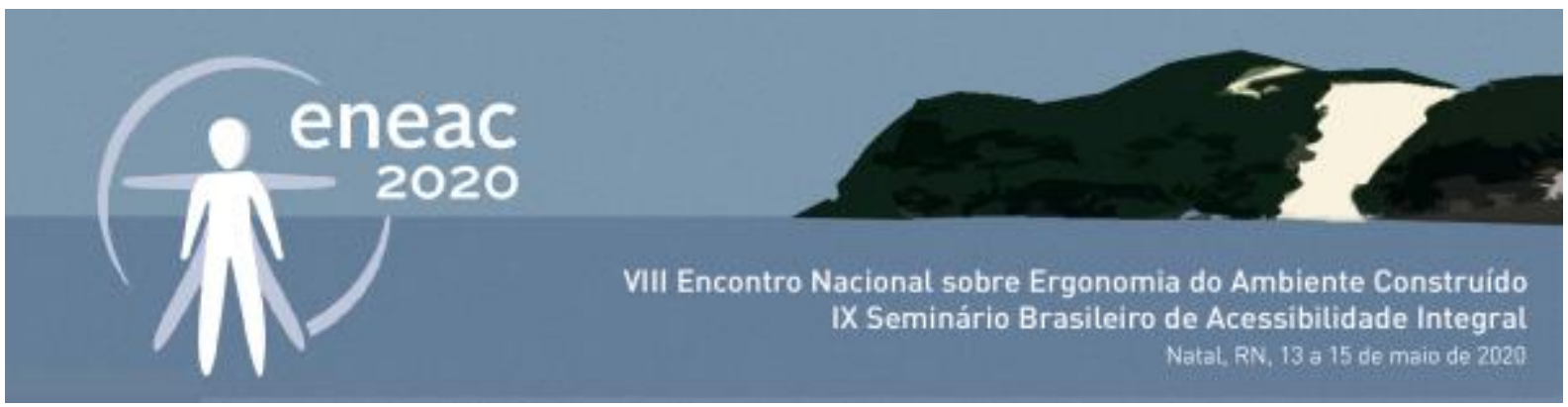

Figura 12: Desenhos das Impressões desenvolvidos pelas crianças

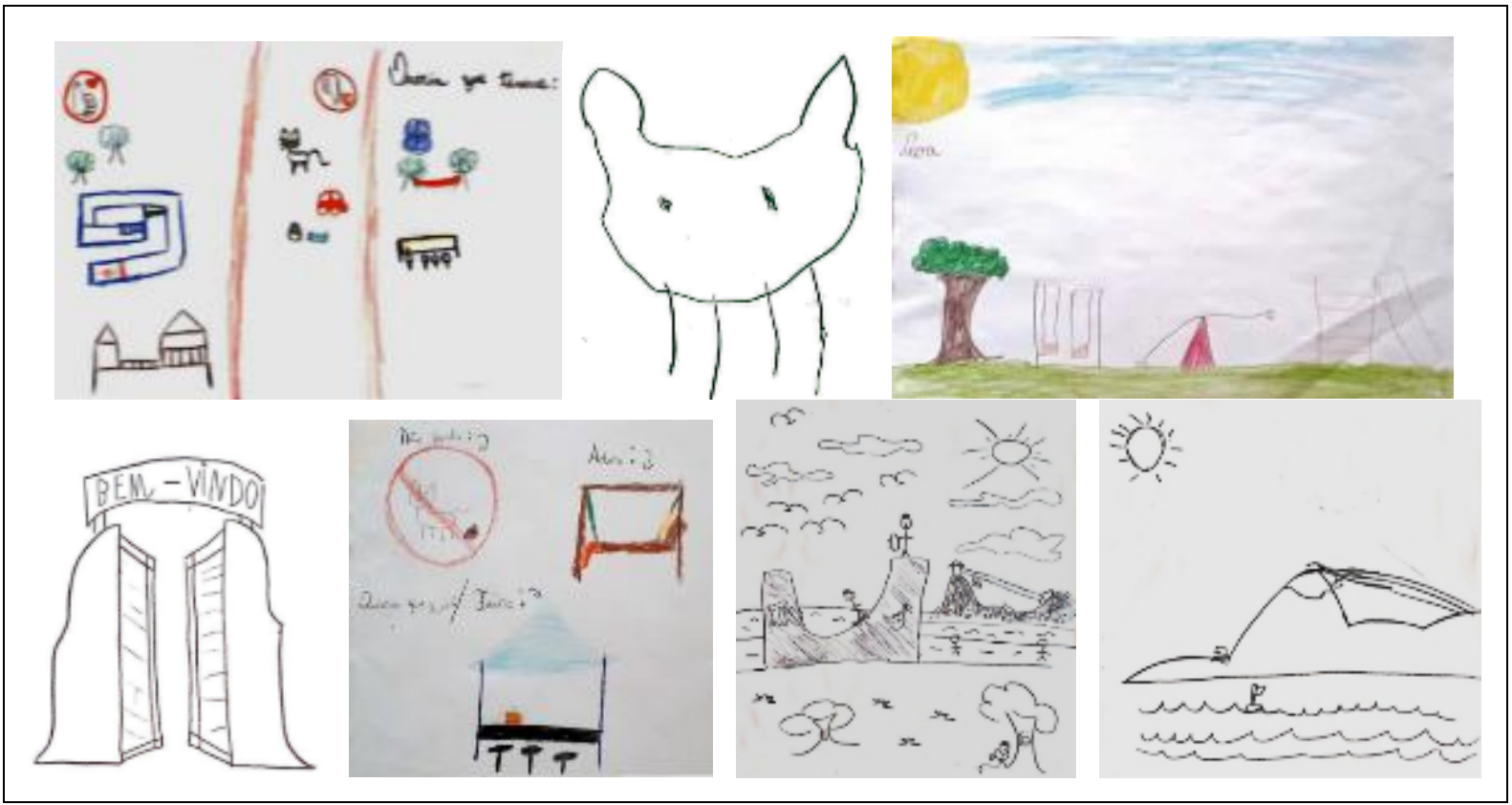

Para demonstrar graficamente o resultado desta pesquisa, para cada avaliação de sentimento representada pelos emojs (figura 13) e cada atividade proposta (figura 14) representada por desenhos, foi atribuída uma cor correspondente. Essa cor foi utilizada como referência para a demarcação na planta baixa do Parque, representando a avaliação de cada usuário. Dessa forma foi possível visualizar as avaliações das ambiências em planta, mapeando os sentimentos e percepções do espaço. Observou-se que nos espaços onde os "emojis" de avaliação apontados foram em sua maioria o "muito legal" e o "legal", as atividades propostas foram similares à setorização existente. Já nos espaços onde a avaliação não foi positiva, as atividades propostas foram diferentes das existentes. Este resultado com as atividades propostas foi mapeado na figura 14

Figura 13: Mapa de avaliação das percepções

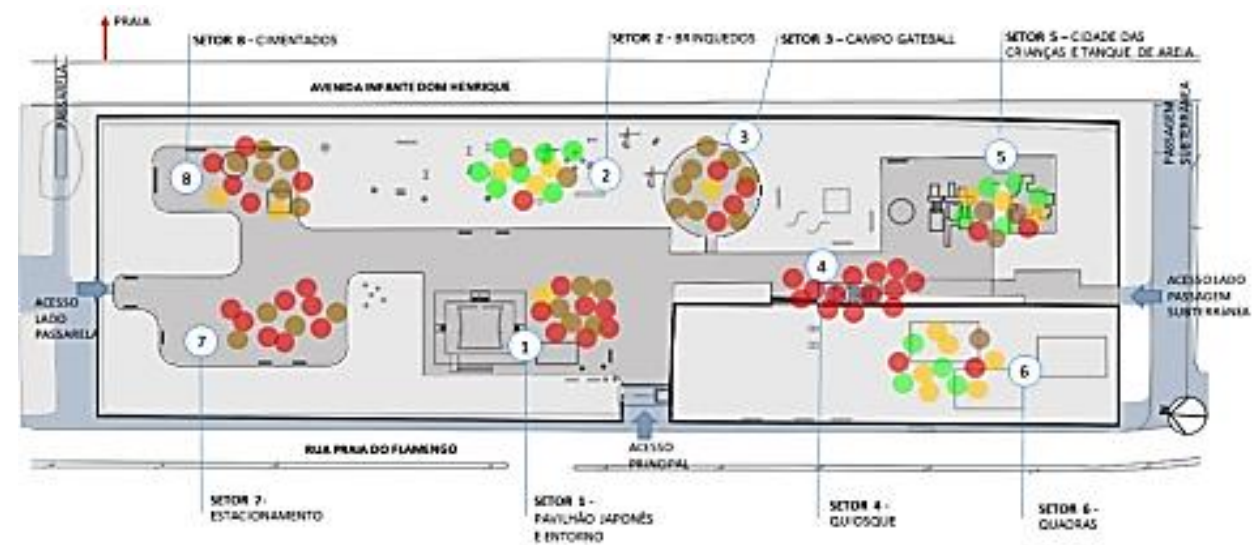



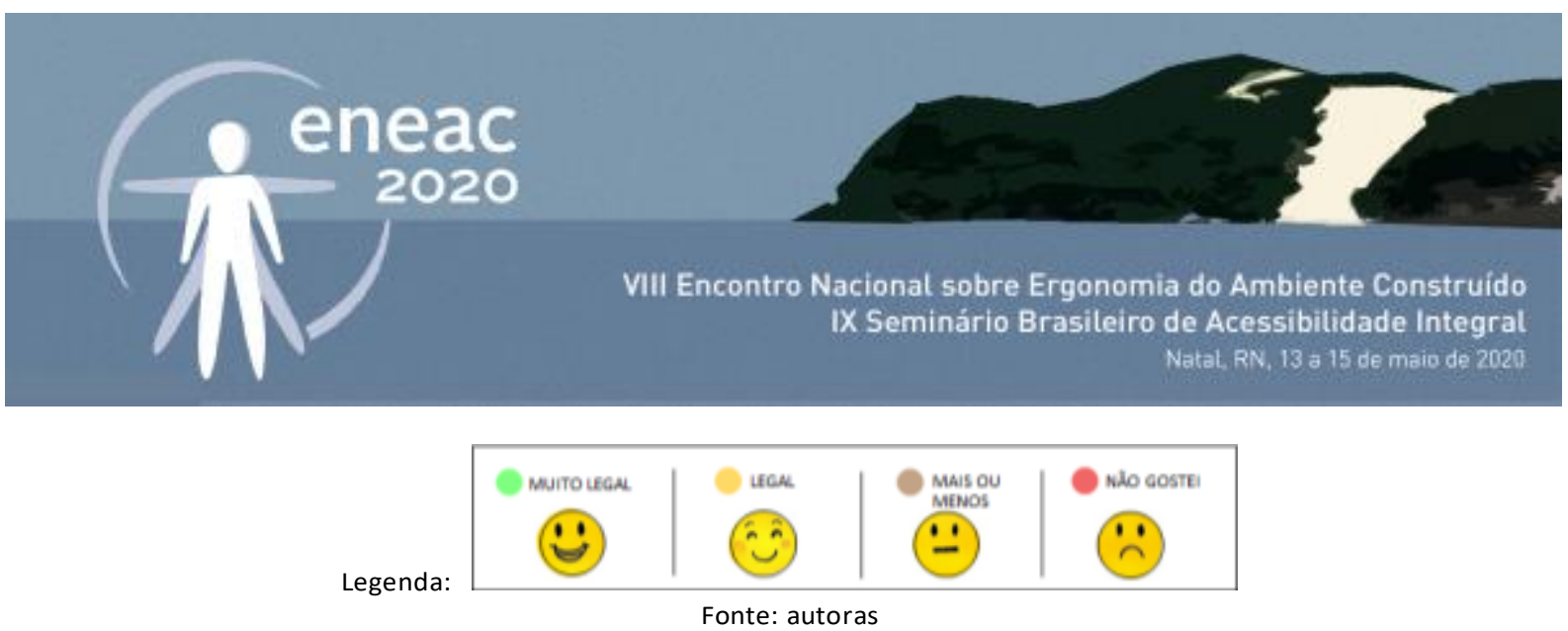

O mapeamento das avalições dos setores do parque revelou que, nos locais onde existem equipamentos e instalações atrativas para os usuários, a avaliação do espaço é mais positiva. Já nos espaços onde não existe uso, a avaliação não foi positiva, mesmo sendo um espaço equipado, como o caso do campo de gateball. Por não apresentar interesse ao usuário, mesmo estando em bom estado de conservação não apresenta interesse aos usuários.

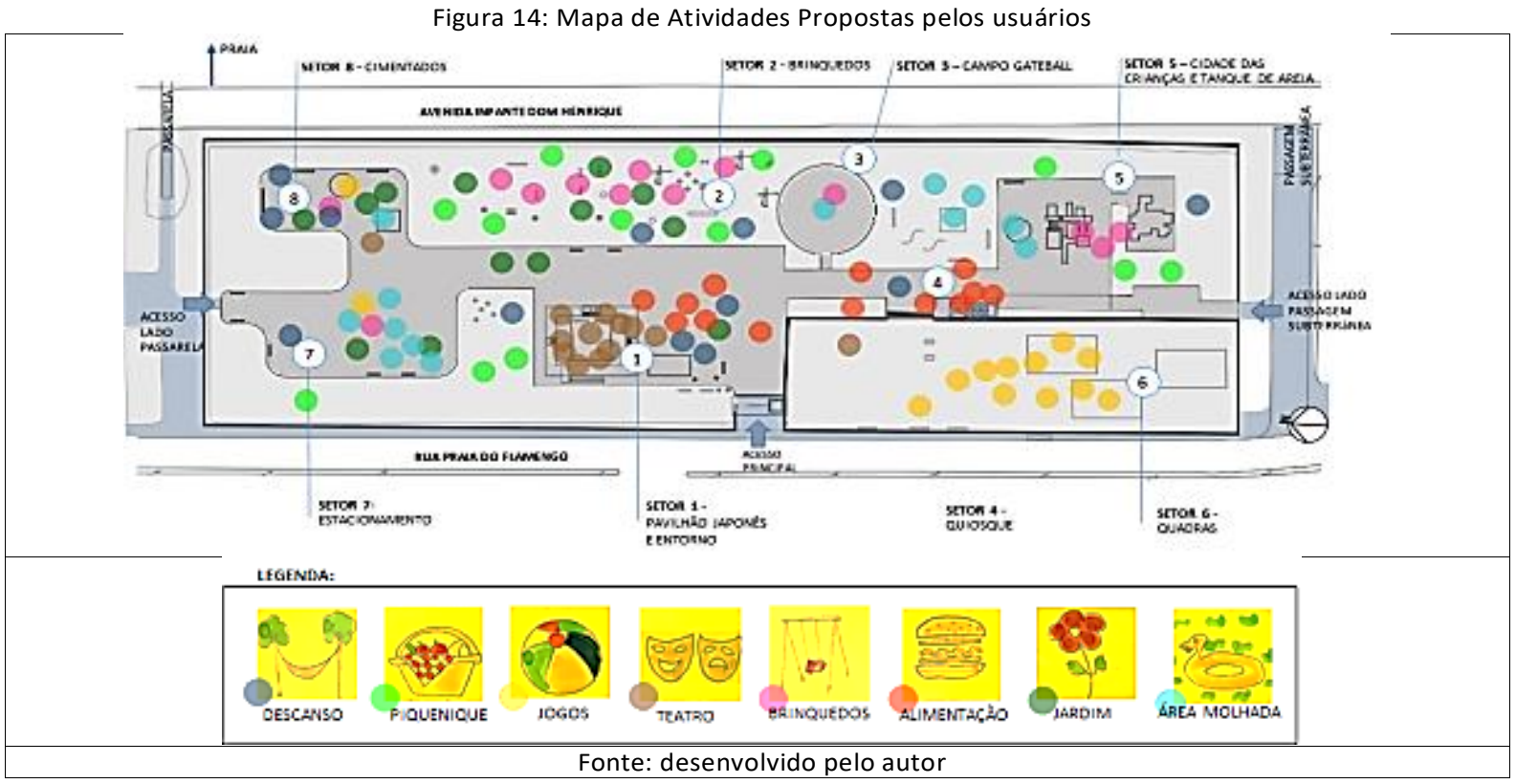

Em todos os setores foram identificados problemas com a falta de acessibilidade. Desde a entrada no parque, seguindo por seus percursos internos e chegando a seus espaços setorizados de lazer, não existe um espaço totalmente acessível e acolhedor para se desfrutar.

As percepções mapeadas após a análise das pesquisas aplicadas em campo, somadas aos estudos de contextualização e pesquisa histórica do objeto foram incorporadas, como demonstramos a seguir, no desenvolvimento do projeto conceitual de intervenção arquitetônica e paisagística, visando ao desenvolvimento de um projeto inclusivo, acolhedor e em consonância com o bem cultural.

\section{PROJETO DE INTERVENÇÃO}

As diretrizes de projeto de requalificação da área infantil do Parque do Flamengo visam demonstrar que é possível torná-lo acessível, com o desenvolvimento de proposta de intervenção seguindo as seguintes premissas: a)projeto baseado nos princípios do desenho universal; b)projeto com intenção de proporcionar uma ambiência acolhedora; c)proposta de novos usos de lazer para o Parque, 


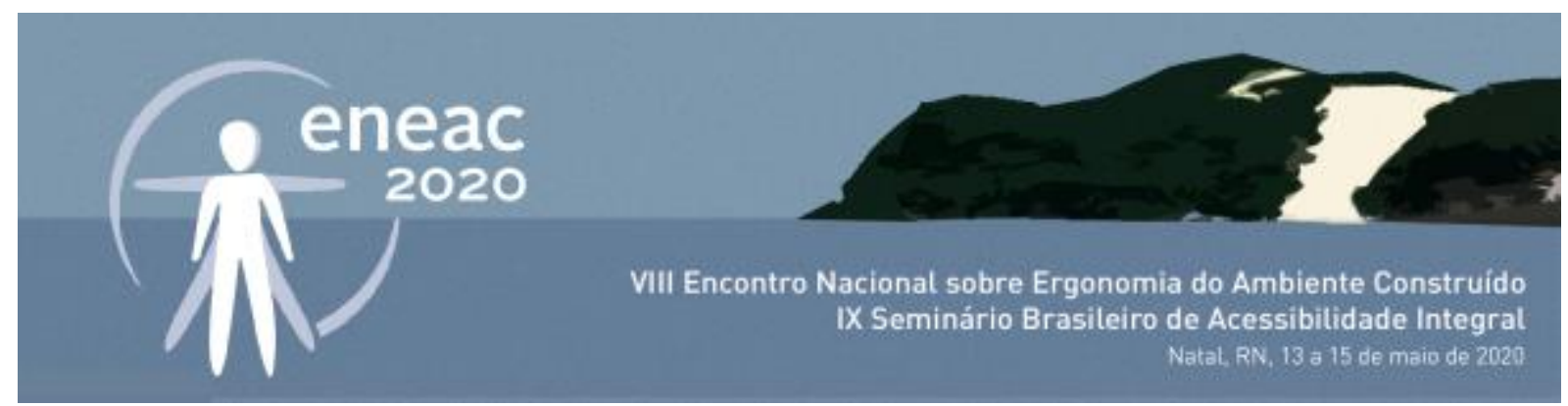

incluindo estrutura de apoio ao usuário; d)intervenção com respeito ao bem cultural preservando seus elementos arquitetônicos e paisagísticos Figura 15).

As dimensões deste artigo não permitem a explicação completa do projeto, mas ao pincelar aqui alguns resultados, entendemos que seja importante frisar que essas diretrizes nortearam a proposta de requalificação, com base nos conceitos de Acessibilidade, de Acessibilidade Emocional (DUARTE E COHEN, 2012) e nas premissas do Desenho Universal, procurando oferecer o acesso de todos ao espaço, sem segregações. A livre circulação entre os ambientes criados no projeto permite que o usuário defina seus percursos e experimentações.

Figura 15: Planta de implantação

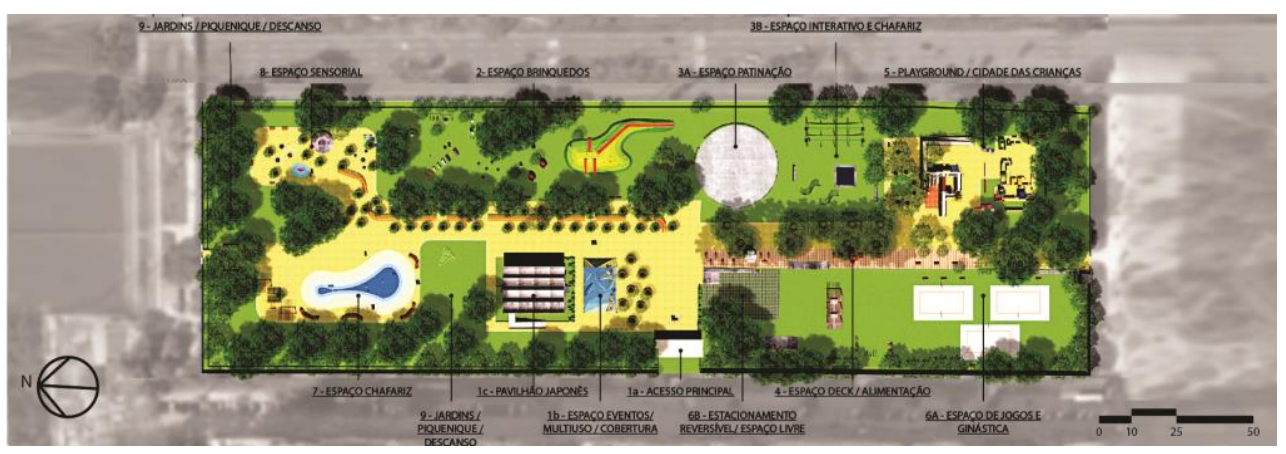

Fonte: autoras

O partido de intervenção adotado para permitir esse livre acesso, foi definido com a retirada de barreiras de circulação no Parque e em suas instalações. Foram propostas rampas de acesso confortáveis e em local de destaque nas áreas sem acessibilidade. Incluindo os acessos aos elementos construídos de lazer pré-existentes (Playground e Cidade das Crianças).

Para permitir a fluidez entre os setores do Parque, os pisos propostos foram nivelados nos trechos de encontro entre a circulação existente e os canteiros de áreas verdes. Essa definição proporciona acesso aos canteiros e cria um fluxo seguro para os usuários. A instalação de golas de árvore neste piso, além da funcionalidade drenante, também proporciona mais segurança à proteção das espécies e circulação dos usuários.

Para trazer mais conforto e segurança, é proposta a substituição do piso da circulação, mantendo a tonalidade parecida com o saibro existente e sua paginação, em consonância com a estética paisagística existente. Destacamos para o atendimento das diretrizes projetuais de acessibilidade, a especificação de novos equipamentos de lazer e de mobiliário, que fossem acessíveis (brinquedos, mesas de piquenique, mesas de jogos, mobiliário no geral como o exemplo da Figura 16). 

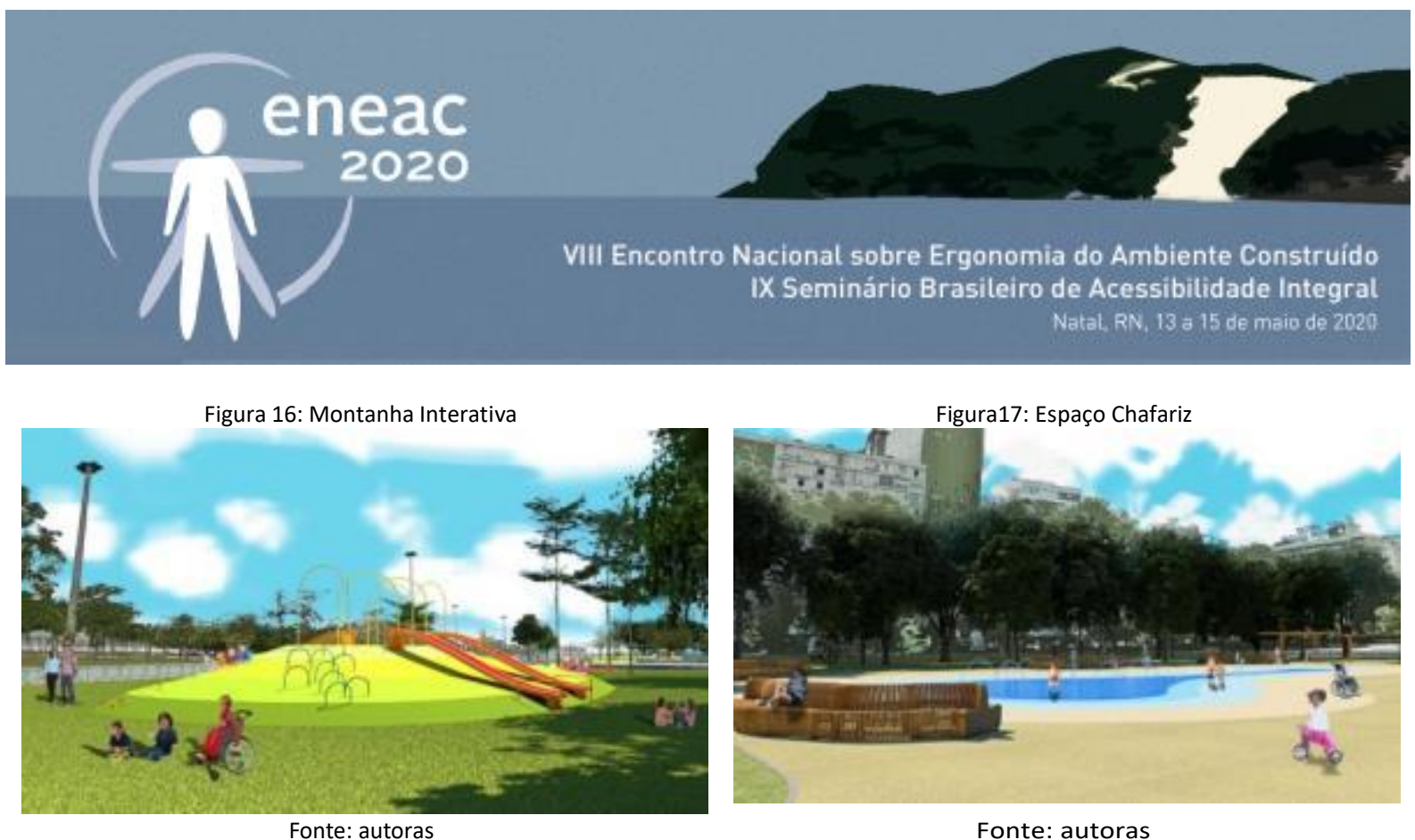

Fonte: autoras

Com base no conceito de Acessibilidade Emocional (DUARTE e COHEN, 2012), são incorporados aspectos sensíveis e afetivos ao projeto. Para o usuário se sentir acolhido no lugar, foi proposto (em projeto) oferecer áreas mais confortáveis, acolhedoras, estimulantes, prazerosas e seguras. Com o intuito de proporcionar novos estímulos sensíveis ao usuário, foi proposta a criação de espaços com área molhada (Figura 17). O elemento água foi incorporado ao Parque em duas instalações de lazer com chafariz de piso: uma grande instalação ao lado do Pavilhão e outra próxima ao Playground, na outra extremidade do Parque. As áreas molhadas, trazem oportunidade da criança interagir com outra materialidade, traz mais frescor ao ambiente e oferece uso a espaços livres sem arborização, muito quentes e de pouca permanência.

A implantação da cobertura em tela translúcida (Figura 19) também foi importante para trazer essa ambiência de acolhimento e conforto na recepção e permanência dos usuários no Parque. A infraestrutura de apoio projetada (sanitários, espaço alimentação e mesas de piquenique) também visa melhorar a experiência das pessoas no local e garantir que se sintam seguras e confortáveis.
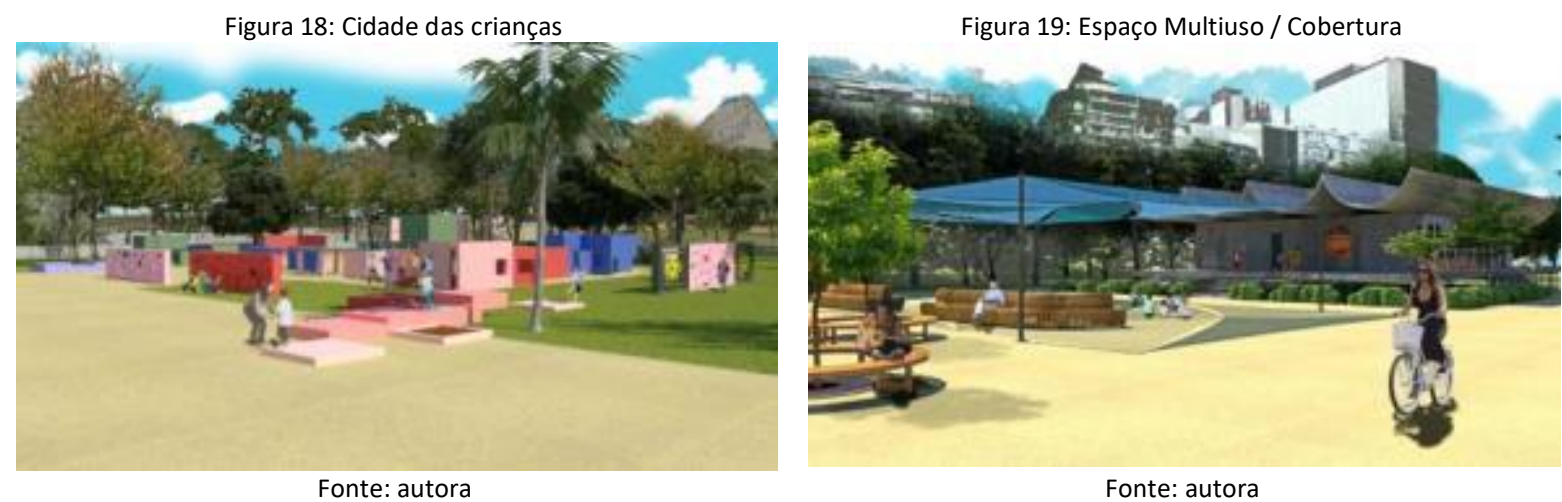

Elementos lúdicos foram sugeridos para desenvolvimento cognitivo e de estímulos sensoriais do usuário, destacando-se: paredes e módulos interativos, elementos sonoros, floresta sensorial, túnel, montanha interativa, redes de descanso à sombra das árvores e as áreas molhadas (Figura 18). Essas instalações oferecem oportunidades para sensações de percepção de materialidades, cores, sons e formas distintas.

A sinalização também foi incorporada como um instrumento que complementou a integração dos setores do Parque, proporcionando informação e conhecimento do bem cultural a todos. A disposição dos pontos foi disposta em pontos estratégicos para garantir a autonomia e funcionalidade da comunicação. 


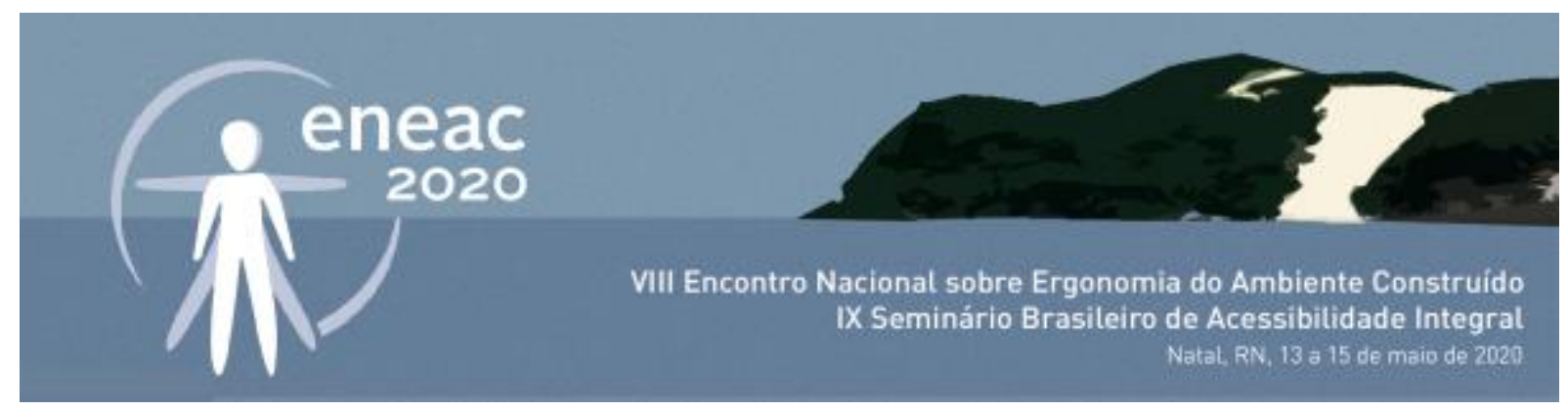

A proposta de projeto traz um conjunto de elementos que estimulam os sentidos, divertem, acalmam, interagem e melhoram a qualidade de conforto do espaço, para promover um Parque acessível e acolhedor.

Com base no conceito da importância do lazer na infância que destaca esta atividade como essencial à vida humana, valorizamos em projeto, o uso das atividades voltadas ao lazer infantil. Essa diretriz manteve a natureza original do Parque. Vislumbramos esse espaço como uma oportunidade de promover uma ampla possibilidade de desenvolvimento de suas habilidades sociais, físicas e emocionais. Valorizamos no projeto a promoção de espaços de lazer com qualidade, criatividade e respeito ao bem arquitetônico e paisagístico.

\section{CONSIDERAÇÕES FINAIS}

Este trabalho buscou refletir sobre as possibilidades e a pertinência de tornar um bem tombado acessível a todos, evitando a segregação e trazendo o usufruto dos espaços públicos a todos os cidadãos. Procuramos focar o projeto na importância da inclusão de crianças em espaços públicos de lazer infantil, de forma não apenas permitir o acesso de todos, mas principalmente, transformar o espaço público em uma fonte de aprendizado, de prazer e de integração entre todas as crianças, independente de suas diferenças.

O estudo de caso do Parque do Flamengo se tornou um objeto adequado para essa reflexão, uma vez que, na especificidade do Parque das Crianças, encontramos usos desvirtuados dos espaços originalmente propostos e instalações degradadas ou inadequadas que contribuíram para entendermos, analisarmos e resolvermos a proposta de requalificação.

De fato, por ser o Parque do Flamengo um dos lugares mais icônicos da Cidade do Rio de Janeiro, amado pelos cariocas e parte do sítio do Patrimônio Mundial da Paisagem Cultural da Cidade, sustentamos ser inadmissível que uma parcela importante da população seja impedida de usufruir desse espaço adequadamente.

Como foi mostrado, tivemos o privilégio de contar com a participação de dois grupos de crianças que muito contribuíram para o desenvolvimento de nossas reflexões. Tanto o primeiro grupo, constituído por crianças que não possuem dificuldades de locomoção ou quaisquer deficiências sensorial ou intelectual, quanto o segundo grupo, constituído por crianças com deficiência e com Transtorno do Espectro Autista foram fonte de riquíssimas informações sobre suas percepções, sentimentos e visões de mundo.

Para melhor compreendê-las, inspiramo-nos na ferramenta metodológica do Mapeamento das Manifestações (DUARTE, 2010) e no Método dos Percursos Comentados (THIBAUD, 2013) para captar as sensações das crianças e mapeá-las. Contudo, visando à captura dessas informações sem que o público infantil perdesse o foco e respondesse a contento, foram desenvolvidas possibilidades de resposta por meio de emojis e de desenhos. A ludicidade da proposta foi responsável por um adequado número de respostas por parte das crianças. As anotações de cunho etnográfico, o levantamento fotográfico e os croquis de campo vieram complementar os dados para análise. Foi possível, assim, identificar as relações de repulsa, atração e afetividade com o ambiente que nos levaram às definições de diretrizes projetuais de intervenção no projeto de requalificação aqui proposto. 


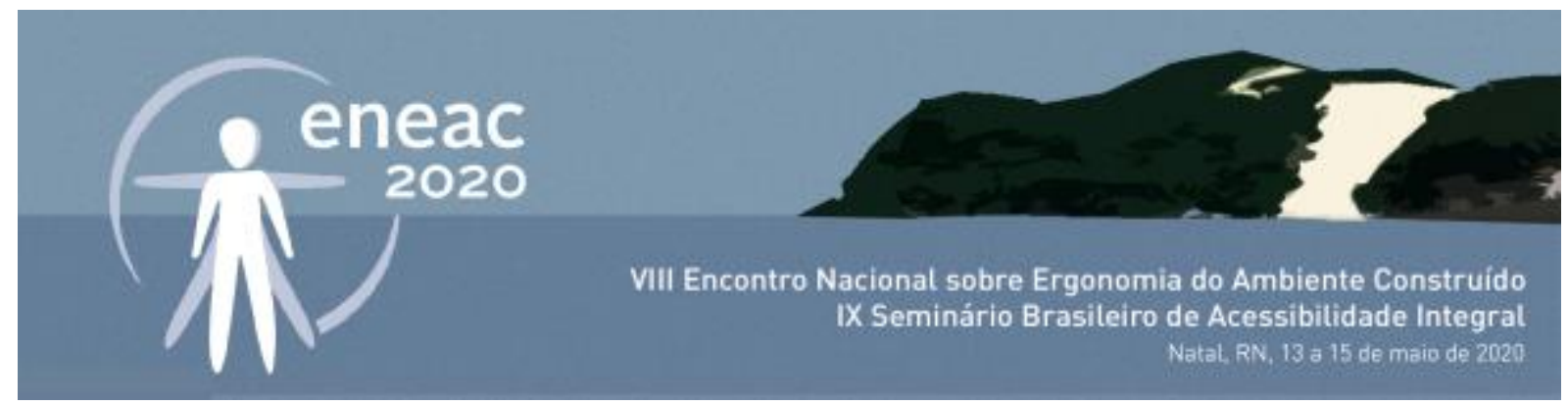

O projeto de intervenção em um bem cultural nos fez perceber que é possível promover a acessibilidade e novos usos ao bem, e ainda assim, preservar sua identidade e características que o constituem como Patrimônio. Portanto, este trabalho nos fez acreditar que as ações de intervenção não devem ser encaradas como barreiras para a preservação do bem cultural. A partir do entendimento de que a acessibilidade agrega valor ao uso, devemos incorporar seus conceitos nos projetos de intervenção, para que o próprio bem atenda suas funções sociais para todos.

\section{REFERÊNCIAS}

ASSOCIAÇÃO BRASILEIRA DE NORMAS TÉCNICAS (ABNT). NBR 9050:2015. Acessibilidade de pessoas portadora de deficiência a edificações, espaço, mobiliário e equipamento urbanos. Rio de Janeiro:2015.

BRASIL. Lei $n^{\circ}$ 13.146, de 6 de julho de 2015. Lei Brasileira de Inclusão da Pessoa com Deficiência (Estatuto da Pessoa com Deficiência). Disponível em: www.planalto.gov.br/ccivil_03/_ato2015-2018/2015/Lei/L13146.htm. Acesso em: fev. 2018

CARSALADE, Flávio de Lemos. A preservação do patrimônio como construção cultural. Arquitextos, São Paulo, ano 12 , n. 139.03, Vitruvius, dez. 2011. Disponível em: http://www.vitruvius.com.br/revistas/read/arquitextos/12.139/4166.

DOSSIÊ DA CANDIDATURA DA CIDADE DO RIO DE JANEIRO A PAISAGEM CULTURAL BRASILEIRA . UNESCO, 2017 . Disponível em: www.unesco.org/new/pt/brasilia/about-this-office/single-view/news/rio_de_janeiro_receives_from_unesco_the_certificate_of_world/ Acesso em: 25 Jul. 2018

DUARTE, C. R.; COHEN, R. "Acessibilidade Emocional”. In: VII Encontro Nacional de Ergonomia do Ambiente Construído / VIII Seminário Brasileiro de Acessibilidade Integral, 2018, Fortaleza. Blucher Design Proceedings. São Paulo: Editora Blucher, 2018. p. 6.

DUARTE, C.R. Olhares possíveis para o Pesquisador em Arquitetura. Rio de Janeiro: Encontro Nacional da Associação Nacional de Pesquisa e Pós-graduação em Arquitetura e Urbanismo, 2010.

DUARTE, C.R.\& COHEN, R.-“Acessibilidade e Desenho Universal: Fundação e Revisão Bibliográfica para Pesquisas”- Relatório Técnico do Núcleo Pró Acesso, 2012.

DUARTE, Cristiane Rose . A Empatia Espacial e sua Implicação nas Ambiências Urbanas. Revista Projetar, outubro 2015.

HISTÓRIA DO PARQUE. Parque do Flamengo, 2018. Disponível em: http://www.parquedoflamengo.com.br/sobre-o-parque/ Acesso em: 30, março 2019

INSTRUÇÃO NORMATIVA №1: 2003. Disponível em: http://diariodorio.com/historia-do-parque-aterro-do-flamengo/, 2016. Acesso em: 30 maio de 2017.

PRADO, A. R. A.; LOPES, M. E.; ORNSTEIN,S. W. (Orgs.) . Desenho Universal: caminhos da acessibilidade no Brasil. São Paulo: Annablume Editora, 2010.

THIBAUD, Jean Paul. Commented City Walks, Journal of mobile culture, 2013, vol4 (no1) pp.1-32.<hal-00980752>

THIBAUD, Jean Paul e DUARTE, Cristiane Rose (orgs). Ambiances urbaines en partage. Genève : MétisPresses, 2013 